AperTO - Archivio Istituzionale Open Access dell'Università di Torino

\title{
Intensification of organic reactions with hybrid flow reactors
}

\section{This is the author's manuscript}

Original Citation:

Availability:

This version is available http://hdl.handle.net/2318/81756

since 2018-02-20T13:22:27Z

Published version:

DOI:10.1016/j.cep.2010.07.004

Terms of use:

Open Access

Anyone can freely access the full text of works made available as "Open Access". Works made available under a Creative Commons license can be used according to the terms and conditions of said license. Use of all other works requires consent of the right holder (author or publisher) if not exempted from copyright protection by the applicable law. 


\section{(5) \\ UNIVERSITÀ DEGLI STUDI DI TORINO}

This Accepted Author Manuscript (AAM) is copyrighted and published by Elsevier. It is posted here by agreement between Elsevier and the University of Turin. Changes resulting from the publishing process - such as editing, corrections, structural formatting, and other quality control mechanisms - may not be reflected in this version of the text. The definitive version of the text was subsequently published in [Chemical Engeneering and Processing, Vol. 49, issue: 9, 2010, doi:10.1016/j.cep.2010.07.004].

You may download, copy and otherwise use the AAM for non-commercial purposes provided that your license is limited by the following restrictions:

(1) You may use this AAM for non-commercial purposes only under the terms of the CC-BY-NC-ND license.

(2) The integrity of the work and identification of the author, copyright owner, and publisher must be preserved in any copy.

(3) You must attribute this AAM in the following format: Creative Commons BY-NC-ND license (http://creativecommons.org/licenses/by-nc-nd/4.0/deed.en), doi:10.1016/j.cep.2010.07.004] 


\title{
Intensification of organic reactions with hybrid flow-reactors
}

\author{
G. Cravotto ${ }^{a *}$, W. Bonrath ${ }^{b}$, S. Tagliapietra ${ }^{a}$, C. Speranza ${ }^{a}$, E. Calcio Gaudino ${ }^{\mathrm{a}}$, A. Barge ${ }^{\mathrm{a}}$.
}

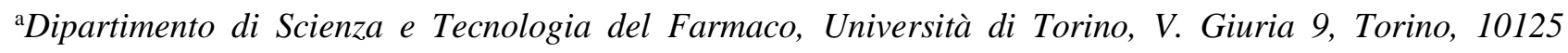
ITALY.

${ }^{\mathrm{b} D S M}$ - Nutritional Products, P.O. Box 2676; CH-4002 Basel, SWITZERLAND.

Corresponding author.

E-mail address: giancarlo.cravotto@unito.it Fax:(+39)-011-670-7687 (G. Cravotto)

Keywords: Flow chemistry, supported catalyst, process intensification, epoxide opening, Friedländer synthesis.

\begin{abstract}
.
The intensification of chemical processes, which means improving their efficiency and cutting down energy consumption, requires more automation and non-conventional energy sources, as well as new, efficient and scalable protocols which need to be implemented in continuous-flow reactors. We showed that flowing systems are advantageous when using conductive heating or non conventional energy sources such as microwave (MW) and ultrasound (US) irradiation. We developed several hybrid flow-reactors suitable for organic reactions with the aim of optimizing heat and mass transfer and achieving process intensification. Here we present a series of applications of a simple flow-reactor that uses an HPLC pump, a column heater and suitable columns filled with a supported catalyst. Using the same column packed with a commercially available derivatized acidic silica we efficiently performed two reaction types: the nucleophilic opening of epoxides with a series of alcohols and the Friedländer quinoline synthesis. In both cases we obtained pure products in excellent yield in a few minutes. The set of experiments on the epoxide opening could be repeated on a hybrid-flow reactor under sequential MW/US irradiation, though at lower temperature. A suitable combination of $1 \mathrm{D}$ and $2 \mathrm{D}$ NMR experiments $\left(\right.$ i.e. ${ }^{1} \mathrm{H}-{ }^{13} \mathrm{C}$ HMQC, ${ }^{1} \mathrm{H}-{ }^{1} \mathrm{H}$ COSY and ${ }^{1} \mathrm{H}_{-}{ }^{1} \mathrm{H}$ NOESY) was applied to unambiguously assign the stereochemistry of hydroxyethers from epoxide cleavage.
\end{abstract}

\section{Introduction}

Flow chemistry is the latest evolutionary step in synthetic chemistry [1]. In recent years, chemistry in flowing systems has become more prominent as a method of carrying out chemical transformations. These systems range in scale from the analytical-scale (microchemistry) up to 
kilogram-scale synthesis [2]. Its advantages may be summed up as readily increased control of conditions often leading to greater reproducibility and scalability, enhanced safety and lower investment, although its acceptance as a viable synthesis technique has been limited by its drawbacks, such as liquid handling, and diffusion of the reaction within the reactor [3]. Thanks to the huge contact surface, flow reactors can optimize mass and heat transfer with state of the art mixing and favourable superheating. They often provide more selective processes and the reaction conditions can be varied independently during the experiment facilitating reaction optimisation. The same results can be achieved by combining US and MW irradiation sequentially in loop-reactors enabling a continuous flow $[4,5]$. Owing to the low penetration depth of US and MW (a few centimetres in both cases) and the high energy consumption, continuous stirred tank reactors (cascade system) are not suitable for combined US/MW irradiation. We therefore envisaged the design of flow reactors for sequential MW/US irradiation. In the prototype shown in figure 1, all the main operative parameters can be strictly and easily controlled. A peristaltic pump circulates the reacting mixture through two separate reaction cells and two thermocouples (inserted at the inlet and outlet of the MW oven) monitor the temperature. There is another pump by which MWtransparent fluids such as silicone oil or fluorinated liquids $\left(\right.$ Galden $\left.^{\circledR}\right)$ which are refrigerated by a chiller, are circulated, in the opposite direction to the reaction flow, through the outer compartment of the coaxial tubing. The number of polytetrafluoroethylene (PTFE) coils inside the oven can be modulated according to the desired volume of the reacting mixture [6].

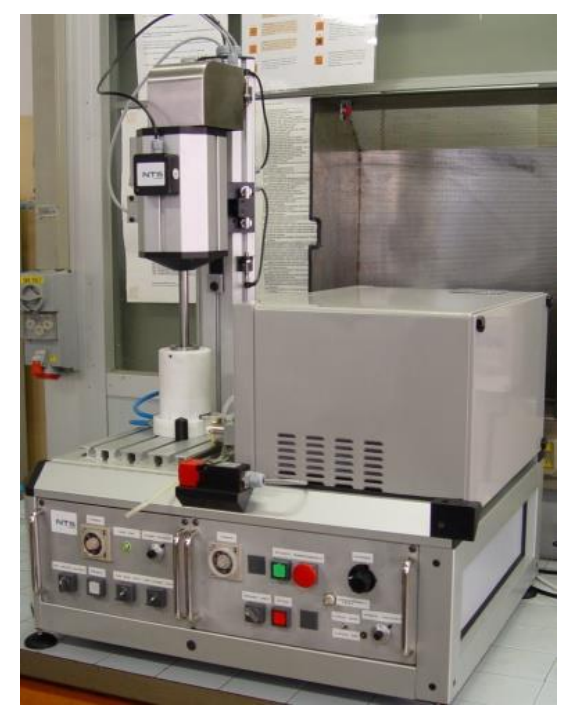

Figure 1. Commercially available system for sequential US/MW irradiation (NTS - Vicenza).

In this type of reactor we successfully performed several kinds of reactions, in particular Pdcatalyzed C-C couplings, including Suzuki homo- and cross-couplings [6], Sonogashira and Heck reactions [7], in addition to Ullmann, Barbier and Reformatzky reactions. The sonochemical 
activation of the metallic catalysts and the accelerating effect of MW heating, led to excellent results in terms of yield and reaction time in all cases [8]. In previous papers we described other reactors developed in our laboratories and mainly used in advanced oxidation processes (AOPs) showing a synergistic effect of the combined US/MW irradiation in the degradation of phenol [9]. Combined US/MW flow-reactors allow outstanding mixing with a turbulent flow (higher Reynolds number) and a higher exchange area between the phases. We also developed a larger semicontinuous US/MW flow-reactor, a 5-litre prototype that included two sonotrodes working at different frequencies (20 and $300 \mathrm{kHz}$ ) and a MW oven [10]. A centrifugal pump circulates the reacting mixture through the reaction compartments, the flow to the US and MW units is regulated by a valve before it is returned to the tank (loop system). Three thermocouples monitor temperatures at the outlet from the MW oven, at the outlet from the US cell and inside the tank [11]. We explored several methods for the intensification of synthetic processes experimenting with other types of flow reactors to exploit solid-supported reagents and catalysts as well as suitable in-line scavengers . This approach is very advantageous as the reaction products alone will remain in solution, thus enabling the reaction to be continually monitored. Compared to standard batch techniques, flow reactors even in absence of US or MW irradiation stand out for their greater efficiency and flexibility, as they fit each synthetic process by optimizing temperature, pressure, residence time and can work in a loop when necessary. The use of supported catalysts or reagents entrapped in the column offers the possibility of recycling the immobilized materials without resorting to any filtration/purification. Avoiding stirring or shaking greatly reduces the mechanical degradation of the catalyst so that it retains its activity for a longer time. As shown by Ley and coworkers [12], the ability to couple the rapid and controlled heating profiles provided by MW irradiation with the fast optimisation and processing capacities of flow chemistry can noticeably favour process intensification in organic synthesis [13].

In the search for new simple and scalable synthetic processes we experimented several reactions in a stop-flow reactor, by adapting an HPLC pump and exhausted semi-preparative HPLC columns to our purposes (Figure 2). We refilled such exhausted columns with suitable inert material mixed to a given supported catalysts. After conditioning the system by thermostatting the column and regulating the solvent flow, the solution containing the reagent and reactant was injected into the system by a Rheodyne ${ }^{\circledR}$ injection valve. This very simple flow reactor can easily be set up in any chemical laboratory without any additional cost by adapting parts of common analytical equipment, though some limitations have to be taken into account due to the solvent pump compatibility. Here we present two efficient synthetic applications of this simple tool, comparing results with those obtained under sequential US/MW irradiation. 


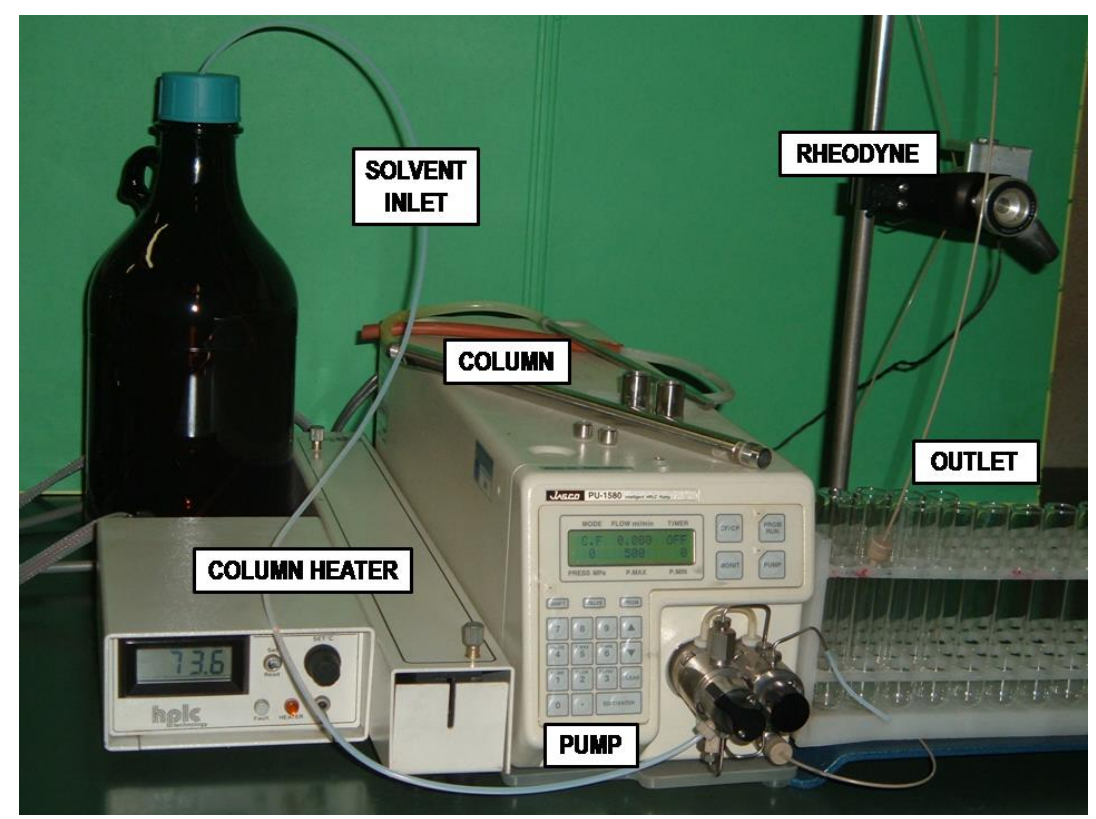

Figure 2. Simple flow reactor composed of a HPLC pump, a column heater and refilled semipreparative columns $(0.8 \times 30 \mathrm{~cm})$.

\section{Results and Discussion}

In a recent paper we disclosed an efficient, catalyst-free synthetic procedure for a regioselective opening of epoxides by some $N$-nucleophiles in water. This result was achieved under simultaneous ultrasound/microwave irradiation that led to a highly accelerated cleavage with high regioselectivity [14]. In the continuous search for extremely efficient synthetic procedures and techniques, we conducted a similar nucleophilic cleavage of epoxides with a series of alcohols (primary and secondary). For this application we moved to flow chemistry using empty semipreparative HPLC columns refilled with a commercially available acidic silica bearing sulphonic acid groups [15]. A continuous-flow apparatus for the hydrolytic kinetic resolution of terminal epoxides over silicabound $\operatorname{Co}($ Salen)-complex catalyst was previously described by Annis and Jacobsen [16]. Various recyclable solid catalysts, including, amberlyst resin [17], sulfonic acid-functionalized SBA-15 [18] and polymer [16] have been investigated in the literature. In our setup the acidic silica was finely mixed with inert fuller's earth $(1: 4 \mathrm{w} / \mathrm{w})$ then the column was carefully packed. The solution of epoxide and alcohol was injected and fluxed with cyclohexane (Scheme 1A). The column was thermostatted at $75^{\circ} \mathrm{C}$ and the flow rate was $4 \mathrm{~mL} \mathrm{~min}^{-1}$. In all cases the reaction was extremely fast affording clean hydroxyethers in a high yield (Table 1). We experimented the same reaction in a loop reactor under sequential MW/US irradiation at $45^{\circ} \mathrm{C}$. US enabled efficient heterogeneous catalysis by fine dispersion of the acidic silica, however besides a fast complete conversion, partial degradation or side reactions were observed. 
As is known the opening of styrene oxide (Entries 1-3) is not catalyst-dependent as it takes place in the alpha position [14]. Excellent reaction rates were observed with cyclohexene oxide (Entries 4, 5) and with 1,2-epoxyoctane (Entries 6a), though the latter gave the regioisomer $6 \mathrm{~b}$ as a minor product. Under these conditions, (+)-(1R,2S,4R)-cis-limonene 1,2-epoxide, a tri-substituted oxyrane, shows regioselective cleavage on the less hindered epoxides carbon. This means that the catalytic effect of 3-propylsulfonic acid-functionalized silica on the epoxide opening does not act as a Brönsted acid but exploits different kinds of interactions. In fact, the same experiment carried out in exactly the same conditions but using bare silica instead of acid-functionalized silica gave very poor yields. The three different limonene 1,2-epoxide opening products (entries 7-9) [19-21], which exclusively gave the trans-diaxial hydroxyether [22], were subjected to a series of NMR studies.

\section{Table 1}

Substrates, nucleophiles and yields of the epoxide opening in flow reactors: column + conventional heating and sequential US/MW.

\begin{tabular}{|c|c|c|c|c|c|c|}
\hline Entry & Epoxide & Alcohol & Product & & $\begin{array}{l}\text { Column } \\
\text { convers./isolated } \\
\text { yield [\%] }\end{array}$ & $\begin{array}{c}\text { US/MW } \\
\text { convers./isolated } \\
\text { yield [\%] }\end{array}$ \\
\hline 1 & $\begin{array}{l}\text { styrene } \\
\text { epoxide }\end{array}$ & $\mathrm{MeOH}$ & & [23] & $92 / 84$ & $100 / 68$ \\
\hline 2 & $\begin{array}{l}\text { styrene } \\
\text { epoxide }\end{array}$ & EtOH & & [23] & $88 / 82$ & $99 / 64$ \\
\hline 3 & $\begin{array}{l}\text { styrene } \\
\text { epoxide }\end{array}$ & $\mathrm{iPrOH}$ & & [23] & $86 / 81$ & $98 / 68$ \\
\hline 4 & $\begin{array}{l}\text { cyclohexene } \\
\text { oxide }\end{array}$ & $\mathrm{MeOH}$ & & [23] & $100 / 100$ & $100 / 89$ \\
\hline 5 & $\begin{array}{l}\text { cyclohexene } \\
\text { oxide }\end{array}$ & $\mathrm{EtOH}$ & & [23] & $100 / 100$ & $100 / 83$ \\
\hline 6(a) & 1,2-epoxyoctane & $\mathrm{EtOH}$ & & & 98/93 & $100 / 71$ \\
\hline 7 & $\begin{array}{l}\text { limonene } \\
\text { oxide }\end{array}$ & $\mathrm{MeOH}$ & & [22] & $84 / 79$ & $98 / 60$ \\
\hline 8 & $\begin{array}{l}\text { limonene } \\
\text { oxide }\end{array}$ & EtOH & & [22] & 99/97 & $100 / 68$ \\
\hline 9 & $\begin{array}{l}\text { limonene } \\
\text { oxide }\end{array}$ & $\mathrm{iPrOH}$ & & & $98 / 94$ & $100 / 63$ \\
\hline
\end{tabular}


On the basis of a suitable combination of $1 \mathrm{D}$ and $2 \mathrm{D}$ NMR experiments (i.e. ${ }^{1} \mathrm{H}-{ }^{13} \mathrm{C}$ HMQC, ${ }^{1} \mathrm{H}_{-}{ }^{13} \mathrm{C}$ $\mathrm{HMBC},{ }^{1} \mathrm{H}-{ }^{1} \mathrm{H}$ COSY and ${ }^{1} \mathrm{H}-{ }^{1} \mathrm{H}$ NOESY) we were able to determine the $(1 S, 2 S, 4 R)$ stereochemistry of $\mathbf{8}$, by analogy of $\mathbf{7}$ and $\mathbf{9}$ (Figure 2).
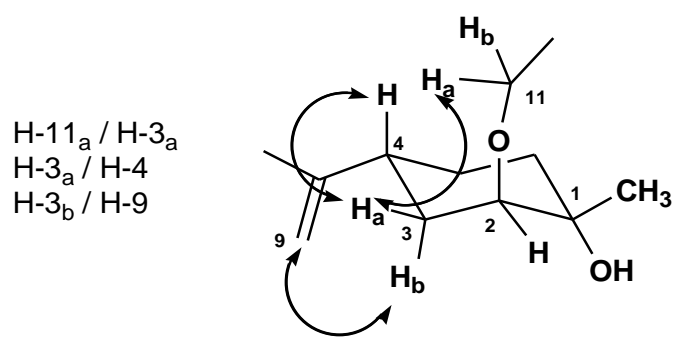

Figure 3. NOE correlation for 8 .

The same column was also used for the Friedländer synthesis of a quinoline derivative with $o$ aminobenzophenone and an enolizable ketone (Scheme 1B). It is worth mentioning that the column was refilled only once close to the end of the investigation when the repetition of Friedländer annulations afforded progressively a lower conversion and yield. Table 2 reports reagents, products and yields, as well as the bibliographic references of analytical data.

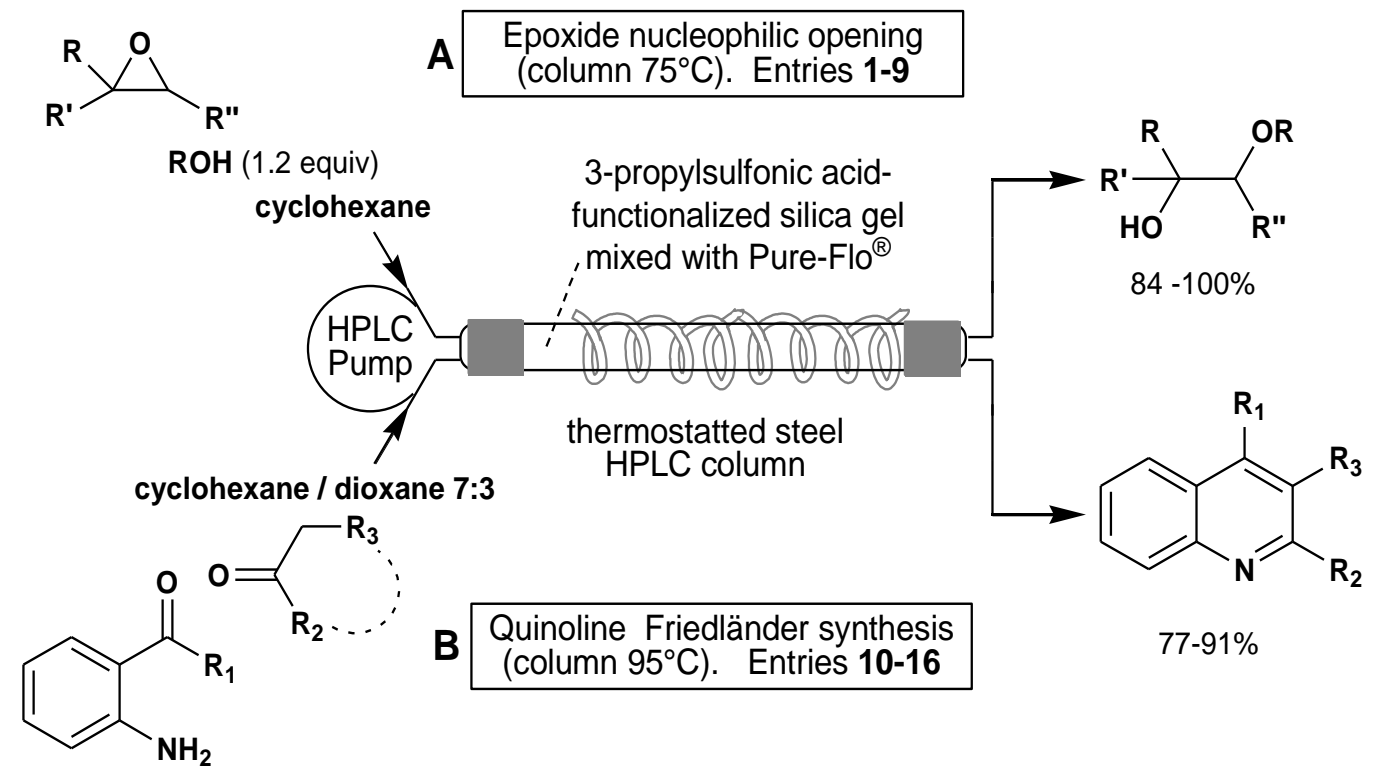

Scheme 1. Two different reactions (A and B) performed in the flow-reactor. 


\section{Table 2}

Friedländer cyclization in flow-reactor.

$\begin{gathered}\text { o-Amino } \\ \text { benzophenone }\end{gathered}$
$\mathbf{1 0}$
$\mathbf{1 1}$
$\begin{gathered}\text { 2-amino } \\ \text { benzophenone } \\ \text { 2-amino-5-chloro } \\ \text { benzophenone }\end{gathered}$

In line with the guidelines of green chemistry and the growing demand for process intensification, we were able to achieve an extremely fast and efficient procedure for selective epoxide opening and for the synthesis of quinolines using a simple flow reactor and a column filled with acidic silica. By getting rid of the reaction work-up, we could obtain the desired product in gram scale merely by repeating the process and simply evaporating the solvent. We showed that flow chemistry can easily be approached by adapting an HPLC system. Our studies once more confirmed that high-throughput applications definitively require flow systems that generally entail much lower investment costs.

\section{Experimental Section}

Reactions were monitored by TLC on Merck $60 \mathrm{~F}_{254}(0.25 \mathrm{~mm})$ plates, which were visualized by UV inspection and/or by heating after being sprayed with $5 \% \mathrm{H}_{2} \mathrm{SO}_{4}$ in ethanol. IR spectra were recorded on a Shimadzu FT-IR 8001 spectrophotometer. NMR spectra were recorded on a Bruker 600 Avance (at $25^{\circ} \mathrm{C}$; chemical shifts are calibrated to the residual proton and carbon resonances of the solvent: $\mathrm{CDCl}_{3}\left(\delta_{\mathrm{H}}=7.26, \delta_{\mathrm{H}} \mathrm{C}=77.0\right)$. Chemical shifts $(\delta)$ are given in ppm, coupling 
constants $(\mathrm{J})$ in Hz. Commercially available reagents and solvents were used without further purification unless otherwise noted. The HPLC pump Jasco PV-1580 and the Rheodyne ${ }^{\circledR}$ injection valve with a $1 \mathrm{~mL}$ loop were connected to a semipreparative HPLC $(0.8$ x $30 \mathrm{~cm})$ column packed with a mixture of 3-propylsulfonic acid-functionalized silica gel (Sigma-Aldrich) (1g, $\sim 0.74$ $\mathrm{mmol} / \mathrm{g}$ loading) and a suitable sorbent with excellent filtration properties (Pure-Flo ${ }^{\circledR}$ Supreme ProActive, Oil Dri - Illinois USA). The column was placed inside a Column Heater TC931 Jasco.

\section{General procedures \\ Opening of epoxides}

(A) Column + conventional heating.

After setting the column thermostat at $75^{\circ} \mathrm{C}$, under flow conditions (cycloexane, $3 \mathrm{~mL} / \mathrm{min}$ ), a mixture of the epoxide $(0.6 \mathrm{mmol})$ and an excess of alcohol $(900 \mu \mathrm{L})$, without any additional solvent (overall volume $=1 \mathrm{~mL}$ ) was injected by the $1 \mathrm{~mL}$ loop and fluxed with cyclohexane. The pure hydroxyether was collected in some test tubes, dried under vacuum and analyzed by TLC (hexane/EtOAc mixtures) and GC-MS.

\section{(B) Sequential US/MW irradiation.}

$500 \mathrm{mg}$ of 3-propylsulfonic acid-functionalized silica gel, cycloexane $(50 \mathrm{~mL})$, the epoxide $(0.6$ $\mathrm{mmol})$ and an excess of alcohol $(1 \mathrm{~mL})$ were placed in the US cell, and circulated through the MW compartment ( $18 \mathrm{~mL}$ loop) for $15 \mathrm{~min}$. The temperature was kept constant at $45-47^{\circ} \mathrm{C}$ by means of the cooling system. The mixture was collected, filtered on a paper disc (Hirsh funnel), dried under vacuum and analyzed by TLC (hexane/EtOAc mixtures) and GC-MS.

(6a) 1-ethoxyoctan-2-ol: Colourless oil. ${ }^{1} \mathrm{H}$ NMR (300 MHz, $\left.\mathrm{CDCl}_{3}\right): \delta 3.75(\mathrm{~m}, 1 \mathrm{H}) ; 3.54(\mathrm{q}, 2 \mathrm{H}$, $\mathrm{J}=5.4 \mathrm{~Hz}) ; 3.43(\mathrm{~m}, 1 \mathrm{H}) ; 3.23(\mathrm{t}, 1 \mathrm{H}, \mathrm{J}=8.4) ; 2.30(\mathrm{~s}, 1 \mathrm{H}) ; 1.41$ (brm, 2H); 1.27 (br, 8H); 1.19 (t, $3 \mathrm{H}, \mathrm{J}=5.7) ; 0.86\left(\mathrm{t}, 3 \mathrm{H}, \mathrm{J}=6.9 \mathrm{~Hz}\right.$ ); GC-MS: m/z calcd for $\mathrm{C}_{10} \mathrm{H}_{22} \mathrm{O}_{2}: 174.16$; found: 174.12 [M ${ }^{+}$. FT-IR: $v\left(\mathrm{~cm}^{-1}\right)=3457,2984,2930,2871,1732,1460,1376,1301,1098$.

(6b) 2-ethoxyoctan-1-ol: Colourless oil. ${ }^{1} \mathrm{H}$ NMR (300 MHz, $\left.\mathrm{CDCl}_{3}\right): \delta 3.63$ (dd, $1 \mathrm{H}, \mathrm{J}=10.5,1.8$ $\mathrm{Hz}) ; 3.5$ (q, $2 \mathrm{H}, \mathrm{J}=9.3 \mathrm{~Hz}) ; 3.44$ (dd, 1H, J = 10.5, $1.8 \mathrm{~Hz}) ; 3.34$ (m, 1H); 2.13 (brs, 1H); 1.51 1.35 (brm, 2H); 1.26 (br, 8H); 1.19 (t, 3H, J = 9.3 Hz); 0.86 (t, 3H, J = 5.7Hz). GC-MS: m/z calcd for $\mathrm{C}_{10} \mathrm{H}_{22} \mathrm{O}_{2}$ : 174.16; found: $174.12\left[\mathrm{M}^{+}\right]$. FT-IR: $v\left(\mathrm{~cm}^{-1}\right)=3421,2997,2924,2875,1724,1458$, $1376,1100$. 
(7) 2-methoxy-1-methyl-4-(prop-1-en-2-yl)cyclohexanol: Colourless oil. ${ }^{1} \mathrm{H}$ NMR (300 MHz, $\left.\mathrm{CDCl}_{3}\right): \delta 4.72(\mathrm{~s}, 2 \mathrm{H}) ; 3.69(\mathrm{~m}, 1 \mathrm{H}) ; 3.19(\mathrm{~s}, 3 \mathrm{H}) ; 2.24(\mathrm{~m}, 1 \mathrm{H}) ; 1.91(\mathrm{~m}, 2 \mathrm{H}) ; 1.70(\mathrm{~s}, 3 \mathrm{H}) ; 1.65-$ $1.39(\mathrm{~m}, 4 \mathrm{H}) ; 1.18$ (s, 3H). GC-MS: m/z calcd for $\mathrm{C}_{11} \mathrm{H}_{20} \mathrm{O}_{2}: 184.15$; found: 184.10 [M ${ }^{+}$]. FT-IR: $v$ $(\mathrm{cm}-1)=3448,2928,2901,2875,1723,1442,1177,1024,885$.

(8) 2-ethoxy- 1-methyl- 4-(prop-1-en-2yl)cyclohexanol: Colourless oil. ${ }^{1} \mathrm{H}$ NMR (300 MHz, $\left.\mathrm{CDCl}_{3}\right): \delta 4.74(\mathrm{~d}, 2 \mathrm{H}, \mathrm{J}=2.7) ; 3.65(\mathrm{~m}, 1 \mathrm{H}) ; 3.40(\mathrm{~m}, 1 \mathrm{H}) ; 3.20($ brs, $1 \mathrm{H}) ; 2.23(\mathrm{~m}, 1 \mathrm{H}) ; 1.81(\mathrm{~m}$, $1 \mathrm{H}) ; 1.75$ (brs, 4H); $1.73(\mathrm{~m}, 1 \mathrm{H}) ; 1.53(\mathrm{~m}, 3 \mathrm{H}) ; 1.27(\mathrm{~s}, 3 \mathrm{H}) ; 1.20(\mathrm{t}, 3 \mathrm{H}, \mathrm{J}=6.6)$. GC-MS: m/z calcd for $\mathrm{C}_{12} \mathrm{H}_{22} \mathrm{O}_{2}$ : 198.16; found: 198.18. [M+ $\mathrm{M}^{+}$. FT-IR: $v(\mathrm{~cm}-1)=3450,2986,2922,2876,1721$, $1430,1167,1024,872$.

(9) 2-isopropoxy-1-methyl-4-(prop-1-en-2-yl)cyclohexanol: Colourless oil. ${ }^{1} \mathrm{H}$ NMR (300 MHz, $\left.\mathrm{CDCl}_{3}\right): \delta 4.74$ (brs, 2H); $3.65(\mathrm{~m}, 1 \mathrm{H}) ; 3.20(\mathrm{~m}, 1 \mathrm{H}) ; 2.27(\mathrm{~m}, 1 \mathrm{H}) ; 2.01(\mathrm{~m}, 2 \mathrm{H}) ; 1.74$ (brs, 3H); $1.55(\mathrm{~m}, 4 \mathrm{H}) ; 1.23(\mathrm{~d}, 6 \mathrm{H}, \mathrm{J}=23) ; 1.16$ (brs, 3H). GC-MS: m/z calcd for $\mathrm{C}_{13} \mathrm{H}_{24} \mathrm{O}_{2}: 212.18$; found: $212.11\left[\mathrm{M}^{+}\right]$. FT-IR: $v\left(\mathrm{~cm}^{-1}\right)=3422,2930,2911,2880,1719,1430,1161,1011,880$.

\section{Friedländer cyclization}

After setting the column thermostat at $95^{\circ} \mathrm{C}$, under flow conditions $(2 \mathrm{~mL} / \mathrm{min}$, cycloexane/dioxane $7: 3)$, the $o$-aminobenzophenone $(0.5 \mathrm{mmol})$ and the ketone $(3 \mathrm{mmol})$ were dissolved in a $7: 3$ cyclohexane/dioxane mixture $(400 \mu \mathrm{l})$ and injected by the $1 \mathrm{~mL}$ loop and fluxed with the same solvents $\left(2 \mathrm{~mL} \mathrm{~min}^{-1}\right)$. The substituted quinoline was collected in some test tubes, dried under vacuum and analyzed by TLC (hexane-EtOAc 3:2) and GC-MS.

\section{Conclusions}

Both research laboratories and the industrial sector are involved in the search for greener synthetic procedures, renewable sources, and new technology that may lead to process intensification. Our experience in flow reactors with non-conventional energy sources such as US and MW as well as our investigations with simple flow systems with columns filled with supported catalysts, confirmed the advantages of flow chemistry.

\section{Acknowledgements}

Financial support from MIUR (PRIN 2008) and the Project NanoIGT (Regione Piemonte and Università di Torino) is gratefully acknowledged. 


\section{References}

[1] C. Wiles, P. Watts, Improving organic reactions using flow reactors, Eur. J. Org. Chem. 10 (2008) 1655-1671.

[2] R.C. Wheeler, O. Benali, M. Deal, E. Farrant, S.J.F. MacDonald, B.H. Warrington, Mesoscale Flow Chemistry: A Plug-Flow Approach to reaction Optimisation, Org. Proc. Res. Develop. 11 (2007) 704-710.

[3] R.V. Jones, C. Csajagi, Z. Szekelyhidi, I. Kovacs, B. Borcsek, L. Urge, F. H. Darvas, The application of flow reactors as a solution to the current drug discovery compound synthesis bottleneck is explored. Chem. Today 26 (2008) 10-12.

[4] G. Cravotto, P. Cintas, Power ultrasound in organic synthesis: moving cavitational chemistry from academia to innovative and large-scale applications, Chem. Soc. Rev. 35 (2006) 180-196.

[5] G. Cravotto, P. Cintas, The Combined Use of Microwaves and Ultrasound: New Tools in Process Chemistry and Organic Synthesis, Chem. Eur. J. 13(7) (2007) 1902-1909.

[6] G, Cravotto, M. Beggiato, G. Palmisano, A. Penoni, J.M. Lévêque, W. Bonrath, High-Intensity Ultrasound and Microwave, Alone or Combined, Promote Pd/C-Catalyzed Aryl-Aryl Couplings, Tetrahedron Lett. 46 (13) (2005) 2267-2271.

[7] G. Palmisano, W. Bonrath, L. Boffa, D. Garella, A. Barge, G. Cravotto, Heck Reactions with Very Low Ligandless Catalyst Loads Accelerated by Microwaves or Simultaneous Microwaves/Ultrasound Irradiation, Adv. Synth. Catal. 349 (2007) 2338-2344.

[8] A. Barge, S. Tagliapietra, L. Tei, P. Cintas, G. Cravotto, Pd-catalyzed reactions promoted by ultrasound and/or microwave irradiation, Curr. Org. Chem. 12 (2008) 1588-1612.

[9] Z.-L. Wu, B. Ondruschka, G. Cravotto, Degradation of Phenol under Combined Irradiation with Microwaves and Ultrasound, Sci. \& Technol. 42 (21) (2008) 8083-8087.

[10] G. Cravotto, V. Tumiatti, C.M. Roggero, Process for the degradation and/or detoxification of chemical and biological pollutants. PCT WO2006 040648 (2006), C. A. 144:418604.

[11] G. Cravotto, S. Di Carlo, M. Curini, V. Tumiatti, C. Roggero, A New Flow Reactor for the Treatment of Polluted Water with Microwave and Ultrasound, J. Chem. Tech. Biotech. 82 (2007) 205-208.

[12] I.R. Baxendale, J.J. Hayward, S.V. Ley, Microwave Reactions Under Continuous Flow Conditions, Comb. Chem. \& High Throughput Screening 10, (2007) 802-836.

[13] T. Van Gerven, A. Stankiewicz Structure, Energy, Synergy, Time-The Fundamentals of Process Intensification, Industrial \& Engineering Chemistry Research, 48 (2009) 2465-2474. 
[14] G. Palmisano, S. Tagliapietra, A. Barge, A. Binello, L. Boffa, G. Cravotto, Efficient Regioselective Opening of Epoxides by Nucleophiles in Water under Simultaneous Ultrasound/Microwave Irradiation, Synlett, 13 (2007) 2041-2044.

[15] D. Garella, A. Barge, D. Upadhyaya, Z. Rodríguez, G. Palmisano, G. Cravotto, Fast, Solvent-Free, Microwave-Promoted Friedlander Annulation with a Reusable Solid Catalyst, Synth. Commun. 40 (2010) 120-128.

[16] D.A. Annis, E.N. Jacobsen, Polymer-Supported Chiral Co(Salen) Complexes: Synthetic Applications and Mechanistic Investigations in the Hydrolytic Kinetic Resolution of Terminal Epoxides, J. Am. Chem. Soc. 121 (1999) 4147-4154.

[17] Y.-H. Liu, Q.-S. Liu, Z.-H. Zhang, Amberlyst-15 as a new and reusable catalyst for regioselective ring-opening reactions of epoxides to $\beta$-alkoxy alcohols J. Mol. Catal. A. Chem. 296 (2008) 42-46.

[18] L. Saikia, J.K. Satyarthi, D. Srinivas, P. Ratnasamy, Activation and reactivity of epoxides on solid acid catalysts J. Catal. 252 (2007) 148-160.

[19] W.F. Newhall, Derivatives of (+)-limonene. III. A stereospecific synthesis of cis- and trans-pmenth-8-ene 1,2-epoxides. J. Org. Chem. 29 (1964) 185-187.

[20] D. Steiner, L. Ivison, C.T. Goralski, R.B. Appell, J.R. Gojkovic, B. Singaram, A facile and efficient method for the kinetic separation of commercially available cis- and trans-limonene epoxide. Tetrahedron Asymm. 13 (2002) 2359-2363.

[21] C.E. Davis, J.L. Bailey, J.W. Lockner, R.M. Coates, Regio- and stereoselectivity of diethylaluminum azide opening of trisubstituted epoxides and conversion of the 3 degrees azidohydrin adducts to isoprenoid aziridines. J. Org. Chem. 68 (2003) 75-82.

[22] N. Iranpoor, P. Salehi, Highly Efficient, Regio-and Stereoselective Alcoholysis of Epoxides Catalyzed with Iron(III) Chloride, Synthesis (1994) 1152-1154.

[23] L.A. Mukhamedova, M.I. Kudryavtseva, R.R. Shagidullin, Yu.Yu. Samitov, Formation of steric isomers in the reaction of limonene oxide with ethanol Izvestiya Akademii Nauk SSSR, Seriya Khimicheskaya 5 (1973) 1061-1067.

[24] B. Das, K. Damodar, N. Chowdhury, R.A. Kumar, Application of heterogeneous solid acid catalysts for Friedlander synthesis of quinolines. J. Mol. Catal. A. Chem. 274 (2007) 148-152.

[25] R. Varala, R. Enugala, S.R. Adapa, Efficient and Rapid Friedlander Synthesis of Functionalized Quinolines Catalyzed by Neodymium(III) Nitrate Hexahydrate, Synthesis 22 (2006) 3825-3830. 